\title{
The Family Dynamics of Elder Elderly in the Context of Porto, Portugal ${ }^{1}$
}

\author{
Lucia Hisako Takase Gonçalves² \\ Maria Arminda Mendes Costa ${ }^{3}$ \\ Maria Manoela Martins ${ }^{4}$ \\ Silvia Modesto Nassar ${ }^{5}$ \\ Roberta Zunino ${ }^{6}$
}

Descriptive study aiming to understand the family dynamics of elderly people aged 80 years or older, receiving family care at home. Caregivers and elderly, registered at the family health unit of Greater Porto, comprised a sample of 107 pairs. Data were collected between 09/2009 and 03/2010. The following instruments were applied: family APGAR, quality of life and lifestyle scale. The results that stand out are: increase in male partners serving as caregivers for dependent partners; substantial inclusion in the list of family caregivers: grandchildren, nieces, nephews, siblings. The caregiver lifestyle was considered regular, as well as the caregiver and elderly's quality of life, although the family dynamics showed to work well. Limitations prevent further generalizations, but offer relevant support for the development of the family health and family nursing program.

Descriptors: Family; Aged, 80 and over; Family Health Program; Family Nursing.

\footnotetext{
${ }^{1}$ Part of the multicenter project DIFAI (Dinâmica da família de idosos mais idosos: o convívio e cuidados na quarta idade nos contextos Florianópolis, SC; Palmeira das Missões, RS; Jequié, BA; Belém, PA e Porto, Pt). Supported by Conselho Nacional de Pesquisa e Desenvolvimento Tecnológico (CNPq), process \# 474154/2008-4.

2 Ph.D. in Nursing. Professor, Universidade Federal de Santa Catarina, SC, Brazil. E-mail: lucia.takase@pq.cnpq.br.

3 Ph.D. in Education. Professor, Universidade do Porto, Portugal. E-mail: arminda@esenf.pt.

4 Ph.D. in Nursing. Professor, Escola Superior de Enfermagem do Porto, Portugal. E-mail: mmartins@esenf.pt.

${ }^{5}$ Ph.D. in Statistics and Computer Science. Professor, Universidade Federal de Santa Catarina, SC, Brasil. E-mail: silvianassar@ctc.ufsc.br.

${ }^{6}$ Nursing undergraduate student, Universidade Federal de Santa Catarina, SC, Brasil. E-mail: roberta.zunino@hotmail.com.
}

Corresponding Author:

Lúcia Hisako Takase Gonçalves

Universidade Federal de Santa Catarina. Centro de Ciências da Saúde.

Programa de Posgraduação em Enfermagem

Campus Universitário Trindade

Bairro: Trindade

CEP: 880400-960 Florianopolis, SC, Brasil

E-mail: lucia@ccs.ufsc.br 


\title{
A dinâmica da família de idosos mais idosos no contexto de Porto, Portugal
}

Este é um estudo descritivo que objetivou conhecer a dinâmica de família de idosos com 80 anos ou mais, sob cuidados do familiar cuidador, em domicílio. Cuidadores e idosos, registrados na unidade de saúde familiar da grande região do Porto, compuseram amostra de 107 unidades. Dados colhidos entre 9/2009 e 3/2010, por instrumentos de dinâmica familiar, qualidade de vida e de estilo de vida, resultaram em: aumento de cuidador masculino e de cônjuge idoso de seu par dependente e inclusão substancial no elenco de familiares cuidadores: netas(os), sobrinhas(os) e irmãs(os). Estilo de vida do cuidador revelou-se regular como também a qualidade de vida de ambos: cuidador e idoso, apesar de a dinâmica de família se mostrar de boa funcionalidade. Limitações impedem a generalização dos resultados, porém, fornece subsídios relevantes para o desenvolvimento do programa de saúde familiar e de enfermagem de família.

Descritores: Família; Idoso de 80 Anos ou mais; Programa Saúde da Família; Enfermagem de Família.

\section{La dinámica de la familia de ancianos con edad avanzada en el contexto de la ciudad de Porto, Portugal}

\begin{abstract}
Se trata de un estudio descriptivo, que tuvo por objetivo conocer la dinámica de familia de ancianos con 80 años o más, bajo cuidados de familiar, en su domicilio. El cuidador y el anciano, que estaban registrados en la unidad de salud familiar de la grande región de la ciudad de Porto, en Portugal, compusieron la muestra de 107 sujetos pareados. Los datos fueron recolectados entre 09/2009 y 03/2010 por medio del APGAR familiar, de calidad de vida y de estilo de vida; los resultados mostraron: aumento de cuidador masculino; conyugue anciano dependiente de su par; e, inclusión substancial de familiares en el elenco de cuidadores (nietas(os), sobrinos(os), hermanas(os). A pesar de la dinámica de la familia mostrarse de buena funcionalidad, el estilo de vida del cuidador y la calidad de vida de ambos (cuidador y anciano) se mostraron regulares. Las limitaciones del estudio impiden la generalización de los resultados; sin embargo ofrece subsidios relevantes para el desarrollo del programa de salud familiar y de enfermería de familia.
\end{abstract}

Descriptores: Familia; Anciano de 80 o Más años; Programa de Salud Familiar; Enfermería de la Familia.

\section{Introduction}

All over the world but mainly in developed countries, especially in the European Union, issues resulting from population aging and people's increased longevity have raises a wide range of discussions, notably regarding public policies for healthcare and prolonged and continuous care delivery to the aging population ${ }^{(1)}$. Since the end of the 1990's, Portugal has been demonstrating demographic structure changes, with increasing numbers of elderly people (aged 65 years and older) in relative as well as absolute terms. The $2001^{(2)}$ census reveals that
Portugal has a population of 10.356 million inhabitants, $16.4 \%$ of whom are elderly (1.693 million), almost half of whom are elder elderly $(690,125)$, indicating simultaneous aging inside the range. The elderly population's distribution is not homogeneous though: socioeconomic asymmetry coincides with geographical asymmetry between the cost and the interior, the latter with its older and poorer population. Mainly associated with unfavorable socioeconomic conditions, longevity negatively affects elderly people's functionality, 
weakening them. Poverty mainly affects the elderly(2), as the current risk rate of poverty in the elderly (24\%) is higher than the general rate (15\%). Many elderly may stay active and fully independent until the end of their days, despite concrete threats of prevalent chronicdegenerative illnesses(3). The prevalence of Chronicity and longevity have contributed to increase the number of elderly with functional impairments, implying constant care by health services and, mainly, by families ${ }^{(3-4)}$. This care is generally delivered at home, with one family member notably assuming the responsibility as the main caregiver. Other family members can help in complementary activities, which is why they are called secondary caregivers ${ }^{(5-6)}$. Home is seen today as a space where dependent people, whether elderly or not, can remain stable and preserve their quality of life. The home care experience has become increasingly frequent in daily family life ${ }^{(6-7)}$. In line with this trend, elderly care policies defend that the home is the best place for the elderly to get old, with possibilities of guaranteeing autonomy and preserving their identity and dignity. Taking care of dependent elderly affected by chronic or acute conditions constitutes a frequent condition in families.

Across history, in most countries, women have delivered care to the elderly, mainly wives, daughters and granddaughtres, which is explained by women's traditional essentially domestic and family functions. Women's progressive participation in the job market, among other factors, however, has modified this reality. Nevertheless, they have been playing the role of caregivers, accumulating their care and domestic activities, besides going out to work. This burden has contributed to negligence of other people and has compromised their own health ${ }^{(5-7)}$. Although current literature signals the multiple characteristics and needs of families who take care of dependent elderly, contextualized knowledge is lacking, considering that these elderly have become older, more or less fragilized depending on the circumstances, indicating new upcoming demands. Thus, this study aimed to get to know the dynamics of family functioning in the context of day/night care relations between the caregiving family and the elder elderly ( 80 years and older) relative who is dependent for care.

\section{Family dynamics - a conceptual framework}

When examining family dynamics, it is important to explore its relations, which reveal harmony or disharmony in the functioning of the care unit, like in the present case, in which one family member is dependent, the elderly who is weak due to advanced age, demanding protection, care, solidarity, affection and love from the family. The idealization of the family as a context of protection and care, however, can take the form of a place of violence and oppression ${ }^{(7-8)}$. In view of that possibility, assessment is essential for health intervention purposes. The APGAR ${ }^{(8-9)}$, an efficient family functioning screening test, assesses the following dimensions through five questions: adaptation, partnership, growth, affection and resolve. The family function refers to the way family members see the family when attending to this commitment and permits identifying individual perceptions of family values as a psychosocial or social support resource. The way people perceive the efficacy and quality of this resource wil significantly influence their health status. Healthy families demonstrate the integrity of these components as they represent the support and care unit. Higher APGAR scores demonstrate the family's greater capacity to adapt to the new situation and possible and probable role changes, while a low score can represent a stressful environment, marked by low adaptability to the new situation, thus demanding fast and appropriate interventions.

\section{Method}

In this exploratory, diagnostic assessment study, participants were pairs of main family caregivers and elder elderly dependent for healthcare and activities of daily living. Porto, located on the North coast of Portugal, was the study context. Greater Porto ${ }^{(2,10)}$ concentrates a population of 263,131 inhabitants. According to demographic projections, its rate corresponds to $19.4 \%$, higher than the country's mean rate (16.4\%) and 51.047 in absolute figures, $32,517(63.7 \%)$ of whom are women and $18,530(36.3 \%)$ men. The age group of 85 years and older is equivalent to $3,947(1.5 \%)$.

The Ministry of Health is working to set up Family Health Units across the Portuguese territory(11-12) and that is where elderly living in the family context are registered. Family health team nurses have been essential, participating in the families' linking around health promotion and care actions in the community and domestic sphere. Family Health Units in Porto have increased, currently corresponding to 64 out of 119 existing unit across the North of the country(11-12). The target population in this study comprised families of elderly care dependents at the age of 80 and older, living in the domestic-family context and whose 
family members are responsible for controlling their life and health. A convenience sample was obtained, locating the pairs at the Family Health Units with higher concentrations of elderly people and with easier access for the research team. The following inclusion criteria were defined to select the participants: families registered at the Family Health Unit and for whose elderly members home visits were indicated because they were care-dependent; both members of the pair able to answer the researcher's questions and, at the same time, voluntarily accepting to participate in the study; also, at the time of data collection, the elderly should not be hospitalized. Data were collected between $09 / 2009$ and $03 / 2010$. The selected pairs were invited and, after their acceptance, they signed the Informed Consent Term and the instruments were applied. The QPFC - Caregiving Family Profile Questionnaire(13) was applied to the family caregiver to answer identification questions regarding sociodemographic variables, health status and care situations of both the family caregiver and dependent elderly. To the elderly, the abovementioned Family APGAR ${ }^{(8-9)}$ was applied, with five simple questions on intra-family adaptation, contact and communication, growth and development, family affection and dedication, with the following response alternatives: always, almost always, sometimes, rarely and never, corresponding to four, three, two points, one point and zero, respectively. Assessment is based on the total score, classifying the family in three types: highly functional, functional, moderately functional and severely dysfunctional. Validity and credibility studies for this test guarantee the safety of its application ${ }^{(9)}$. To complement the family dynamics results, individual perceptions of correlated aspects like quality of life and lifestyle were also assessed. Thus, the WHOQOL(14-16), the quality of life assessment instrument developed by WHO, was applied to the family members and elderly. The WHOQOL-Bref version, with 26 questions, covering four domains and preserving the twentyfour facets of the original WHOQOL-100, was applied to the relatives. Each question is accompanied by five Likert-style alternative answers, ranging from 1 to 5 . For the elderly, besides the WHOQOL - Bref, the 24question WHOQOL - Old was applied, which includes specific aspects like: Sensory functioning; Autonomy; Past, present and future activities; Death and dying; and Intimacy. All WHOQOL versions were tested, with good validity and reliability scores(15-16). Moreover, to family members, the Scale of Wellbeing was applied(17), which assesses the lifestyle through behaviors that affect health. This scale assesses five habitual actions: nutrition, physical activities, preventive behaviors for health, social relations and stress control, reflecting people's attitudes, values and opportunities. Each action contains three items, totaling 15 questions. Answer scores can range from zero to 3 for each item. The maximum total score is 45 , corresponding to an excellent lifestyle, and the minimum zero, which represents and inadequate lifestyle. Tests revealed acceptable validity and reliability ${ }^{(17)}$. With a view to replication in different centers, this project was submitted to the Institutional Review Board at UFSC (where the project coordination was located), in compliance with Resolution 196/96 by the Brazilian Ministry of Health National Health Council. Approval was registered under No 051/08.

\section{Results}

\section{Sample characteristics}

The sample includes 107 elder elderly and their respective main family caregivers, as shown in Tables 1 and 2.

Table 1 - Characteristics of elder elderly receiving family care at home, Greater Porto, Portugal, 2010

\begin{tabular}{|c|c|c|}
\hline Sample characteristics - Elderly $(n=107)$ & $\mathbf{n}$ & $\%$ \\
\hline \multicolumn{3}{|l|}{ Age per range } \\
\hline Up to 84 & 59 & 55.1 \\
\hline 85 to 89 & 42 & 39.2 \\
\hline 90 or more & 6 & 5.6 \\
\hline \multicolumn{3}{|l|}{ Gender } \\
\hline Male & 29 & 27.1 \\
\hline Female & 78 & 72.9 \\
\hline \multicolumn{3}{|l|}{ Education } \\
\hline Illiterate & 30 & 28.1 \\
\hline Pre-school until 4 years & 53 & 49.6 \\
\hline Unfinished/finished first year elementary school & 10 & 9.2 \\
\hline Unfinished/finished first year elementary school & 14 & 13.1 \\
\hline \multicolumn{3}{|l|}{ Marital status } \\
\hline Married & 34 & 31.8 \\
\hline Divorced/separated/single & 19 & 17.7 \\
\hline Widowed & 54 & 50.5 \\
\hline \multicolumn{3}{|l|}{ Age of elderly's spouse } \\
\hline Mean in years /SD & $84 / 4.5$ & \\
\hline \multicolumn{3}{|l|}{ Professed religion (Catholic) } \\
\hline Yes & 103 & 97.0 \\
\hline \multicolumn{3}{|l|}{ Parenthood with family caregiver } \\
\hline Son/Daughter & 50 & 46.7 \\
\hline Nephew/Niece & 19 & 17.8 \\
\hline Partner & 18 & 16.8 \\
\hline Sister & 11 & 10.3 \\
\hline $\begin{array}{l}\text { Others (brother, daughter-in-law, son-in-law, } \\
\text { friend and granddaughter) }\end{array}$ & 9 & 8.9 \\
\hline
\end{tabular}


Table 1 - (continuation)

\begin{tabular}{lcc}
\hline \multicolumn{1}{c}{ Sample characteristics - Elderly (n=107) } & $\mathbf{n}$ & $\%$ \\
\hline House where the elderly lives & 15 & 14.0 \\
$\quad$ Owned/usufruct & 66 & 61.7 \\
$\quad$ Rented & 26 & 24.3 \\
$\quad$ Of caregiver/other relative & & \\
Diseases suffered & 60 & 56.1 \\
$\quad$ Arterial Hypertension & 24 & 22.4 \\
$\quad$ Sequela of CVA & 20 & 18.7 \\
$\quad$ Heart disease & 22 & 20.6 \\
$\quad$ Diabetes mellitus & 16 & 14.9 \\
$\quad$ Cancer (colon, breast, lung, bladder, skin and & 7 & 6.5 \\
stomach) & & \\
$\quad$ Parkinson's Disease & $62.0 / 11.9$ & \\
Mean Quality of Life scores (WHOQOL-Bref 0-100) & \\
$\quad$ Mean scores/SF & $67.0 / 13.1$ & \\
Mean Quality of Life scores (WHOQOL-Old 0-100) & & \\
$\quad$ Mean scores/SF & & \\
Family Dynamics Apgar & 72 & 67.3 \\
$\quad$ Good Functionality (Scores 13-20) & 20 & 14.0 \\
$\quad$ Moderate dysfunctionality (Scores 9-12) & 15 & 18.7 \\
$\quad$ Severe dysfunctionality (Scores 0-8)
\end{tabular}

Most participants in the sample are women and widowed. On the other hand, $31.8 \%$ of the sample were still married, even at the age of 80 years and older, half of whom receive care from their spouse.

Table 2 - Characteristics of main family caregivers for elderly aged 80 years and older, dependent on care, Greater Porto, Portugal, 2010

\begin{tabular}{|c|c|c|}
\hline $\begin{array}{l}\text { Sample characteristics - Caregiver for the } \\
\text { elderly ( } \mathrm{n:107)}\end{array}$ & $\mathbf{n}$ & $\%$ \\
\hline \multicolumn{3}{|l|}{ Age } \\
\hline Mean in years/SD & $58 / 15.4$ & \\
\hline \multicolumn{3}{|l|}{ Gender } \\
\hline Male & 43 & 40.2 \\
\hline Female & 64 & 59.8 \\
\hline \multicolumn{3}{|l|}{ Marital Status } \\
\hline Married & 76 & 71.0 \\
\hline Divorced/separated/single & 27 & 25.2 \\
\hline Widowed & 4 & 3.7 \\
\hline \multicolumn{3}{|l|}{ Education } \\
\hline Illiterate & 3 & 2.8 \\
\hline Pre-school until 4 years & 22 & 20.5 \\
\hline $\begin{array}{l}\text { Unfinished/finished first year elementary } \\
\text { school }\end{array}$ & 49 & 45.8 \\
\hline $\begin{array}{l}\text { Unfinished/finished first year elementary } \\
\text { school or unfinished higher education }\end{array}$ & 33 & 30.8 \\
\hline \multicolumn{3}{|l|}{ Occupation/Work } \\
\hline Yes & 40 & 38.0 \\
\hline \multicolumn{3}{|l|}{ Takes care of other dependents } \\
\hline Yes & 27 & 25.0 \\
\hline \multicolumn{3}{|l|}{ Lives with the elderly receiving care } \\
\hline Yes & 80 & 75.0 \\
\hline & & inue \\
\hline
\end{tabular}

Table 2 - (continuation)

\begin{tabular}{lcc}
\hline $\begin{array}{c}\text { Sample characteristics - Caregiver for the } \\
\text { elderly (n: 107) }\end{array}$ & n & $\%$ \\
\hline $\begin{array}{l}\text { Self-appreciated health } \\
\text { Excellent / good }\end{array}$ & 38 & 35.5 \\
$\quad$ Regular & 61 & 57.0 \\
$\quad$ Bad / very bad & 8 & 7.5 \\
Quality of Life -WHOQOL/Bref, 0-100 & & \\
$\quad$ Mean score/SD & $73.0 / 12.3$ \\
Lifestyle-Nahas scale, 0-45 & \\
$\quad$ Mean score/SD & $26.2 / 4.4$ \\
\hline
\end{tabular}

Caregivers' mean age is 58 years, ranging between 30 and 89 years. Most of them are married, many still go out to work and take care of other dependents in the family. When asked about how they perceive their own health, the regular health response prevailed. This perception is equivalent to quality of life and lifestyle assessment, which also obtained regular scores.

\section{Quality of life of the elderly and family caregiver}

Quality of life(14-16) represents the individual perception of one's position in life in the context of the culture and value system one is inserted in and related to objectives and expectations, standards and concerns. This perception has an important subjective value, as it directly influences one's state of wellbeing, health and the feeling of greater or lesser competency to administer one's own life under any circumstance. The elderly people's responses to the WHOQOL-Bref scored low in the physical and social relations domain: relatives, on the other hand, self-assessed themselves with lower scores in the environment and psychological domains, as observed in Table 3.

Table 3 - Mean scores and standard deviations on WHOQOL-Bref domains (range 0-100) for elderly and caregivers, Greater Porto, Portugal, 2010

\begin{tabular}{lccccc}
\hline \multirow{2}{*}{$\begin{array}{c}\text { WHOQOL-Bref } \\
\text { domain }\end{array}$} & \multicolumn{2}{c}{ Mean } & & \multicolumn{2}{c}{ Standard deviation } \\
\cline { 2 - 3 } \cline { 5 - 6 } \cline { 5 - 6 } & Elderly & Caregiver & & Elderly & Caregiver \\
\hline Physical & 48.4 & 76.5 & & 20.8 & 15.9 \\
Psychological & 53.0 & 65.7 & & 15.3 & 14.8 \\
Social Relations & 50.9 & 71.5 & & 14.7 & 14.3 \\
Environment & 58.7 & 64.1 & & 12.3 & 12.4 \\
\hline
\end{tabular}

Table 4 shows the mean scores per age range on the WHOQOL Old. The general mean score was influenced by higher scores on Sensory functioning, Social participation and Death and dying. 
Table 4 - Mean and standard deviation of WHOQOL-Old (range 0-100) domain scores for the elderly per age range, Greater Porto, Portugal, 2010

\begin{tabular}{|c|c|c|c|c|c|c|}
\hline \multirow{3}{*}{ WHOQOL-OId domain } & \multicolumn{6}{|c|}{ Age Range } \\
\hline & \multicolumn{2}{|c|}{ Up to 84} & \multicolumn{2}{|c|}{85 to 89} & \multicolumn{2}{|c|}{90 or more } \\
\hline & Mean & SD & Mean & SD & Mean & SD \\
\hline Sensory functioning & 76.2 & 20.9 & 62.6 & 27.4 & 40.6 & 33.2 \\
\hline Autonomy & 53.1 & 20.9 & 62.1 & 19.2 & 60.1 & 30.3 \\
\hline Past, present and future activities & 56.2 & 14.8 & 59.2 & 15.7 & 53.1 & 9.5 \\
\hline Social participation & 47.1 & 20.7 & 54.5 & 17.8 & 36.5 & 21.4 \\
\hline Death and dying & 46.2 & 33.6 & 47.6 & 37.3 & 58.3 & 46.5 \\
\hline Intimacy & 69.5 & 21.7 & 76.6 & 22.1 & 81.2 & 22.1 \\
\hline
\end{tabular}

The analysis of the association between the WHOQOL-Bref and WHOQOL-Old scores, tested using Spearman's correlation coefficient, resulted in r 0.63013, with statistical significance $p<0.000001$. This coefficient was adopted because data did not show normal distribution. A moderate positive relation is evidenced between both instrument scores.

\section{Family functionality}

The assessment of family dynamics from the perspective of the elderly, through the application of the Family APGAR, demonstrates that most elderly in this study see their family as a care relations unit, which good or moderate functionality (Tabela 1 ).

\section{Caregivers' Health-related Lifestyle}

Lifestyle was assessed through the Scale of Wellbeing(17), with a total mean score of 26.2 , within a possible range from zero to 45 . Caregivers' lifestyle was considered regular, equivalent to the regular results for quality of life too.

\section{Discussion}

The predominance of elderly women in the sample confirms the trend of the already known feminilization of old age $\mathrm{e}^{(2,10)}$. The low education level found was also predictable, in view of the preceding reality of people aged 80 years or older today. The prevalence of chronic-degenerative illnesses constitutes a common epidemiological parameter in aging populations ${ }^{(3-4)}$. The irremediable fact of prolonged contact with chronicity due to increased longevity can make people lose quality of life if the public policy of a continued and integrated care network $^{(18)}$ for the life and health of elderly people is not put in practice. It is important to grant priority coverage to poorer families ( $86 \%$ in this study), which divides the sole resource of elderly people's retirement benefit. In the study, caregivers are still mostly women, including daughters, nieces, granddaughters and sisters, as identified in other studies ${ }^{(5-6,19-20)}$, although a new fact is emerging: the growth in male caregivers. In comparison with an earlier study ${ }^{(5)}$, performed four years ago in the same context, this percentage has doubled. This growth, however, was already appointed in 1999, in a Ministry of Health report on the support program for the elderly ${ }^{(11)}$, estimating that the share of men as informal caregivers figured around 28 to $37 \%$, although little is known about male informal caregivers, even in the international context ${ }^{(21-22)}$, with extremely scarce literature. In our midst(23), a qualitative study involving male elderly caregivers for their sick spouses spent considerable time and energy, against traditional gender stereotypes of attributing family care to women. The reasons for them being caregivers were: duty and obligation, marital commitment, reciprocity and gratitude for longlasting marital life. As for feelings, they experienced a wide and often ambiguous range: satisfaction and pride, but also sadness, frustration and revolt. A similar study ${ }^{(23-24)}$ attempted to question the elderly caregivers' decision to take care of their spouses with dementia conditions. Among the results, the following stood out: love, reciprocal obligations, redemption. According to the author, what makes elderly men decide to take care is probably the crucial element in this experience and probably the main difference between male and female care. Further knowledge on male and particularly elderly caregivers is essential. Nevertheless, any available data entail direct implications for family care practice. Professionals, especially nurses, need to reconsider the stereotype of care always being linked to women. Men need and can be encouraged for this family task, following the example of men who decided to take care of their wives, courageously going against social and cultural values and assuming the care task, classified as eminently female. 
The caregivers studied here live in the same house as the elderly receiving care in $75 \%$ of cases, often motivated by the facility of care, but mainly by families' impoverishment. This data supports some study results ${ }^{(5,7,19-22)}$, particularly highlighting the proportion of $17 \%$ of caregiving partners found here, as confirmed by some studies that mark the increase in elderly caregivers, male and female partners, taking charge of care for their partners. These caregivers also suffer because of feelings of solitude and social isolation, as observed here in quality of life assessments, with lower scores in the psychological and environment domains. Therefore, in practice, local social support networks need to be articulated, based on Health Services, with a view to maintaining families' social inclusion.

Many of the caregivers in this research $(64.5 \%)$ answered that their health was regular or bad, and also showed a lifestyle with a regular total mean score, possibly due to the stress and burden the care task entails, with little time left to take care of themselves and the elderly, besides the exhaustion of their own aging, as demonstrated in many foreign studies and confirmed in some Brazilian ones ${ }^{(5-7,23-24)}$.

From the perspective of the elderly dependent on their relatives' care, the assessment of family dynamics through the application of the Family APGAR demonstrated adequate family functionality in $67.3 \%$. In principle, this more dynamic positive result does not exempt the alert for family care interventions in the new conditions the family experiences regarding the need and expectation of home care for the elderly. It is the place for anticipated intervention to prevent possible family crises $^{(12,19)}$. The study also reveals $32.7 \%$ of elderly living in families with severe and moderate family dysfunction, which should not cause estrangement, as care delivery to an elderly person with chronic illnesses and other problems can develop some form of stress in the family, such as the lack of adaptability to changes in family members' roles, to new intra-family relationship styles and to the care relations themselves. This result remits to family care interventions by professionals, mainly nurses, who are involved in the administration of family difficulties to deal with dependent elderly people's problems that need care or are receiving care. When elderly patients report on a family crisis, in general, family resources are inappropriate to respond to the needs and/or signal the existence of weakened or vulnerable areas in the family context, which may be interfering in family members' ability to find strategies and resources to develop their role as caregivers ${ }^{(10,12,19)}$.
Family members' personal perceptions of certain variables, however, such as quality of life and healthy lifestyle or not, can influence the family dynamics, turning it more or less adaptative, more or less functional, in view of a situation that represents a new fact to cope with: an elderly member who gets ill and becomes more fragile and care-dependent by the day, influencing intrafamily relations.

Both WHOQOL versions equivalently assessed quality of life, as a positive association was found, tested using Spearman's correlation. This confirms the advantages of the WHOQOL - Old, as it permits assessing the particularities of elderly people's more positive or negative perceptions of aspects in the quality of life domains. Both assessments of the elderly fell in the median or regular quality of life classification. On the WHOQOL-Bref, the low mean score in the physical domain, related to health, contributed to a regular total score. On the WHOQOL-Old, the low mean score regarding social participation in the quality of life domains revealed a regular general quality of life level. Assessment according to this version, however, revealed considerable differences among the six aspects and, when their scores were distributed across the age ranges (80-84, 85-89, 90 and +), it was verified that variations are not necessarily regular as age advances, indicating the manifestation of elderly people's particularities, even at more advanced ages.

\section{Final considerations}

Despite the study limitations, whose data were extracted from a convenience sample, which impedes their generalization, results represent useful support for professional practice, mainly for Family nurses. In summary, noteworthy results regarding family caregivers for the elderly tend to change what is found in the literature: increase in male caregivers; increase in elderly caregiving partners; more substantial inclusion of family caregivers, like nieces and nephews, grandchildren, siblings.

Families in this study seem to have a vocation for elderly care, given their favorable assessment of the family dynamics. Caregiver and elderly quality of life, on the other hand, display similar regular assessments. The caregiver's lifestyle revealed regular results, like quality of life. The caregiver's lack of external social opportunities and the elderly's affected health status and wellbeing seem to converge towards a regular or median result. 
Implications for practice entail the need to understand caregiving families not only as partners in care, but also as clientes/users of social and health services.

\section{References}

1. Ministério da Saúde (PT). Direção geral da saúde Plano Nacional de Saúde 2004-2010: mais saúde para todos. Lisboa: Direção Geral de Saúde do Ministério da Saúde de Portugal; 2004.

2. Instituto Nacional de Estatística- INE (PT). O Envelhecimento em Portugal: situação demográfica e socioeconômica recente das pessoas idosas. Estatísticas Censitárias e da População. Lisboa: INE; 2002.

3. Organisation Mondiale de la Santé - OMS. Santé 21: La politique - Cadre de la Santé, pour tous pour la Región Européenne de I'OMS. Série Européenne de la Santé pour tous , n.6 Copenhague: Bereau Regionel de I'Europe, OMS; 1999.

4. Chaimowicz F. Epidemiologia e o envelhecimento no Brasil. In: Freitas EV, Py L, Cançado FAX, Doll J, Gorzoni ML. Tratado de Geriatria e Gerontologia. 2 ed. Rio de Janeiro: Guanabara Koogan; 2006. p. 106-30.

5. Pimenta GMF, Costa MASMC, Gonçalves LHT, Alvarez, AM. Perfil do familiar cuidador de idoso fragilizado em convívio doméstico da Grande Região do Porto, Portugal. Rev Esc Enferm USP. 2009;43(3):609-14.

6. Decreto Lei 309-A/2000, de 30/11/2000 (PT). Altera o artigo 70 do Decreto-Lei no 265/99, de 14/07/99, que procede à criação de uma nova prestação destinada a complementar a protecção concedida aos pensionistas de invalidez, velhice e sobrevivência dos regimes de segurança social em situação de dependência. Diário da República, PT. [periódico na internet], 30 nov 2000. [acesso 25 ago 2010]. Disponível em: http://www.dre. pt/ pdfgratis/2000/11/277A01.pdf

7. Meira EC, Gonçalves LHT, Souza AS, Silva JA, Neri IG. Fatores de risco de maus tratos ao idoso na relação idoso/cuidador em convivência intrafamiliar. Textos Envelhecimento. 2004;7(2):63-84.

8. Gardner W, Nutting PA, Kelleher KJ, Werner JJ, Farley $T$, Stewart $L$, et al. Does the Family APGAR Effectively Measure Family Functioning? J Fam Practice. 2001;50(1):141-9.

9. Duarte YAO. Família: Rede de Suporte ou fator estressor. A ótica de idosos e cuidadores familiares [tese de doutorado]. São Paulo (SP): Escola de Enfermagem de São Paulo da Universidade de São Paulo; 2001. 196 p.
10. Instituto Nacional de Estatística - INE (PT). O envelhecimento em Portugal: Situação demográfica e sócio-econômica recente das pessoas idosas. Rev Estudos Demográficos. 2002; (32):185-208.

11. Ministério da Saúde (PT). Decreto-lei n.301, de 18/94/2008. Enquadramento, organização e funcionamento da Unidade de Saúde Familiar, 2008. Diário da República no 77, Série I, 18 abril 2008.

12. Ordem dos Enfermeiros (PT). A Cada Família o seu Enfermeiro. Lisboa: Ordem dos Enfermeiros, 2002.

13. Gonçalves LHT, Alvarez AM, Santos SMA, Spricigo JS, Portella, MR, Fortes VLF et al. El perfil de la familia cuidadora del anciano enfermo/debilitado em los contextos socioculturales de Florianópolis, SC y Passo Fundo, RS. Rev Panam Enferm. 2005;3:185-94.

14. WHOQOL Group. World Health Organisation - WHO). Measuring quality of life: the development of the World Health Organisation Quality of Life Instrument. Geneve: WHO; 1993.

15. Fleck MP, Louzada S, Xavier M, Chachamovich E, Vieira G, Santos L, Pinzon V.

[Application of the Portuguese version of the abbreviated instrument of quality

life WHOQOL-bref]. Rev Saúde Pública. 2000;34(2):178-

83. Portuguese.

16. Fleck MPA, Chachamovich E, Trentini CM. Projeto WHOQOL-OLD: método e resultados de grupos focais no Brasil. Rev Saúde Pública. 2003;34(6):793-9.

17. Nahas MV, Barrros MVG, Francalacci VL. Pentáculo do bem estar: base conceitual parta a avaliação do estilo de vida de indivíduos e grupos. Rev Bras Atividades Físicas Saúde. 2000;5(2):48-59.

18. Ministério do Trabalho e Solidariedade. Ministério da Saúde (PT). Serviço de Apoio aos Idosos: Relatório de actividades. [internet]. 1999. [acesso 1 ago. 2010]. Disponível em: http://www.ias.gov.mo/pt/stat/ rept1999/ch5/r99-di-p.htm.

19. Delgado, JA. A família vivenciando situações de saúde-doença: um conhecimento em construção. In: Elsen I, Marcon SS, Santos, MRS. O viver em família e sua interface com a saúde e a doença. Maringá: Eduen; 2002. p. 443-56.

20. Mayor MS, Ribeiro O, Paul C. Estudo comparativo: percepção da satisfação de cuidadores de pessoas com demência e cuidadores de pessoas com AVC. Rev. LatinoAm. Enfermagem. 2009;17 (5):620-4.

21. Ducharme F, Lévesque L, Lachance L, Zarit S, Vézine J, Gangbè M, et al. Older husbands as caregivers of their wives: a descriptive study of the context and relational aspect of care. Int J Nurse Studies. 2006;43(5):567-79. 
22. Crocker HS. Methodological issues in male caregiver research: an integrative review of literature. J Adv Nurs. 2002;40(6):626-40.

23. Pinto CVDT, Silva AL. Razão e sensibilidade no cuidado informal: narrativas de homens idosos cuidadores. In: Silva AL; Gonçalves LHT. Cuidado à Pessoa Idosa. Porto Alegre: Sulinas, 2010. p. 238-69.

24. Melo G. A Experiência vivida de homens (cônjuges) que cuidam de mulheres com demência. Rev Bras Geriatr Gerontol. 2009;12(3):319-30. 